\title{
Dissatisfaction and Body Checking in Sports Scale: A New Measure for Athletes ${ }^{1}$
}

\author{
Leonardo de Sousa Fortes \\ Universidade Federal de Pernambuco, \\ Recife-PE, Brazil \\ Edilson Serpeloni Cyrino \\ Universidade Estadual de Londrina, \\ Londrina-PR, Brazil
}

\author{
Sebastião Sousa Almeida \\ Universidade de São Paulo, \\ Ribeirão Preto-SP, Brazil \\ Maria Elisa Caputo Ferreira \\ Universidade Federal de Juiz de Fora, \\ Juiz de Fora-MG, Brazil
}

\begin{abstract}
After performing searches in the main scientific articles database, no specific psychometric scale was found that analyzes body dissatisfaction and body checking to athletes. The aim of the study was to analyze the psychometric properties of the Dissatisfaction and Body Checking in Sports Scale (DBCS) - male and female versions - in Brazilian athletes. The researchers built the DBCS. Participants were 1,197 athletes. The exploratory factor analysis showed a factor structure that explained more than $40 \%$ of the variance in both versions of the DBCS. The results showed a statistically significant relationship between the DBCS - male and female versions - and questionnaires used for concurrent validity $(p<.001)$. No difference was found in mean DBCS scores when applied two weeks apart $(p>$ $.05)$. The findings indicated difference in DBCS scores according to body fat $(p=.01)$. The results showed a positive relationship between DBCS and Eating Attitudes Test scores $(p=.001)$. It was concluded that the DBCS - male and female versions - demonstrated satisfactory concurrent, discriminant, predictive validity and reproducibility.
\end{abstract}

Keywords: body image, athletes, psychometrics

\section{Escala de Insatisfação e Checagem Corporal nos Esportes: Uma Nova Medida para Atletas}

\begin{abstract}
Resumo: Após realizar buscas nas principais bases de dados de artigos científicos, não foi encontrada escala psicométrica específica que avalie insatisfação e checagem corporal em atletas. O objetivo foi analisar as propriedades psicométricas das versões feminina e masculina da Escala de Insatisfação e Checagem Corporal nos Esportes (EICCE) em atletas brasileiros. A EICCE foi construída pelos próprios pesquisadores. Participaram 1.197 atletas de ambos os sexos. Os resultados demonstraram estrutura fatorial que explicou mais de $40 \%$ da variância de ambas as versões da EICCE. Os achados indicaram relação estatisticamente significativa entre as versões da EICCE e os questionários utilizados para a validade concorrente $(p<0,001)$. Não se revelou diferença das médias dos escores da EICCE no teste-reteste $(p>0,05)$. Os achados demonstraram diferença dos escores da EICCE em função da adiposidade corporal $(p=0,01)$. Os resultados apontaram relação positiva entre a EICCE e os escores do Eating Attitudes Test $(p=0,001)$. Concluiu-se que as versões feminina e masculina da EICCE demonstraram validade concorrente, discriminante, preditiva e reprodutibilidade satisfatórias.
\end{abstract}

Palavras-chave: imagem corporal, atletas, psicometria

\section{Escala de Insatisfacción y Chequeo Corporal en los Deportes: Una Nueva Medida para Atletas}

\begin{abstract}
Resumen: Tras búsquedas en las principales bases de datos de artículos científicos, no fue encontrada escala psicométrica para evaluar la insatisfacción corporal y el chequeo corporal en los atletas. El objetivo fue analizar las propiedades psicométricas de la Escala de Insatisfacción y Chequeo Corporal en los Deportes (EICCE) en atletas brasileños. La EICCE fue construido por los investigadores. Participaron 1.197 atletas de ambos sexos. Los resultados demostraron que la estructura factorial explica más del $40 \%$ de la varianza de ambas versiones de la EICCE. Los resultados indicaron una relación estadísticamente significativa entre la EICCE y cuestionarios utilizados para la validez concurrente $(p<0,001)$. No se encontraron diferencias en las puntuaciones medias del EICCE en la fiabilidad test-retest $(p>$ $0,05)$. Los hallazgos demostraron diferencia en las puntuaciones del EICCE en función de la adiposidad corporal $(p=0,01)$. Los resultados mostraron una relación positiva entre EICCE y las puntuaciones del Eating Attitudes Test $(p=0,001)$. Se concluyó que ambas versiones de la EICCE demostraron validez concurrente, discriminante, predictivo y reproducibilidad satisfactorias.
\end{abstract}

Palabras clave: imagen corporal, atletas, psicometría

\footnotetext{
${ }^{1}$ Paper derived from the first author $\mathrm{PhD}$ thesis, under the supervision of the last author, defended in 2016 in the Graduate Program in Psychology at Universidade Federal de Juiz de Fora.

Support: Coordination for the Improvement of Higher Education Personnel (CAPES - Grant 2013/1472-6)

${ }^{2}$ Correspondence address:

Leonardo de Sousa Fortes. Rua Clóvis Beviláqua, 163-1003, Madalena. CEP 50710-330. Recife-PE, Brazil. E-mail: leodesousafortes@hotmail.com
}

Sports competitions are loaded with charges to achieve maximum performance (Fortes, Kakeshita, Almeida, Gomes, \& Ferreira, 2014; Petrie, Galli, Greenleaf, Reel, \& Carter, 2014). Trainers frequently require that their athletes improve their output during trainings and competitions. To a certain extent, the sports performance depends on the body morphology (Fortes, Almeida, \& Ferreira, 2014). Hence, athletes who 
perceive that their morphology is inappropriate for their sport may demonstrate body dissatisfaction, defined as the level of concern with the body (Laus et al., 2014). Although studies have demonstrated a lower degree of body dissatisfaction in athletes when compared to the general population (Francisco, Narciso, \& Alarcão, 2013; Varnes et al., 2013), in another research, it was highlighted that the body dissatisfaction is more related to the sports performance (de Bruin, Oudejans, Bakker, \& Woertman, 2011). In that sense, one can presuppose that the athletes demonstrate a "double" body image: one associated with the sports context and the other related to the general culture.

There are two branches to body dissatisfaction: the drive for thinness (aversion of obesity) and the drive for muscularity (Laus et al., 2014). The main tools used to assess the body dissatisfaction focused on thinness are: Body Shape Questionnaire - BSQ (P.J. Cooper, Taylor, Z. Cooper, \& Fairburn, 1987) and the Body Dissatisfaction subscale of the Eating Disorder Inventory-2 - EDI-2 (Garner, Olmstead, \& Polivy, 1983). For muscularity, the main measures are: Muscularity-oriented body image subscale of the Drive for Muscularity Scale - DMS (McCreary, Sasse, Saucier, \& Dorsch, 2004) and the Body Dissatisfaction Muscularity - BDM (Ochner, Gray, \& Brickner, 2009). These scales were constructed for the general population though. Nevertheless, one important limitation for the use of these measures in athletes is that they have not been appropriately validated in the athletic population and, therefore, may not be suitable to analyze the body dissatisfaction in that audience.

Body checking, described as the frequency of behaviors to check one's own body (Walker, Anderson, \& Hildebrandt, 2009), is considered to maintain the level of body dissatisfaction (Walker, Murray, Lavender, \& Anderson, 2012). Thus, the higher the frequency of body checking, the greater the body dissatisfaction and vice-versa. The tools most used in research to assess the body checking behaviors in the female sex are: Body Checking and Avoidance Questionnaire - BCAQ (Shafran, Fairburn, Robinson, \& Lask, 2004) and Body Checking Questionnaire - BCQ (Reas, Whisenhunt, Netemeyer, $\&$ Williamson, 2002). The only measure developed for the male sex to assess body checking was the Male Body Checking Questionnaire - MBCQ (Hildebrandt, Walker, Alfano, Delinsky, \& Bannon, 2010). Nevertheless, these scales were developed for the general population, and are therefore not specific to assess the frequency of body checking in athletes.

It should be highlighted that body dissatisfaction and body checking are strongly related with the risk behaviors for eating disorders in the athletic population (Fortes, Ferreira, Oliveira, Cyrino, \& Almeida, 2015; Fortes, Kakeshita, et al., 2014). According to Petrie et al. (2014), body dissatisfaction can predict the risk of triggering eating disorders in the medium term among athletes. In addition, although it is not part of the etiology of eating disorders in athletes, body checking also seems to demonstrate a close relation with the risk of developing anorexia and bulimia nervosa (Fortes et al., 2015). In this sense, any tool to assess both dissatisfaction and body checking in the athletic audience should demonstrate predictive validity for the risk behaviors for eating disorders.
It is considered important to build specific psychometric measures for the population one intends to assess (DeVellis, 2003). Therefore, due to the lack of a scale intended to assess body dissatisfaction and body checking behaviors in athletes, the Scale of Dissatisfaction and Body Checking in Sports (EICCE) is presented. The researchers built the EICCE. It is a self-reported tool consisting of 31 items, which aim to assess feelings, thoughts and body checking behaviors in the sports context. In view of the need to construct a psychometric tool to assess the dissatisfaction and body checking in athletes, the objective in this study was to analyze the psychometric properties of the EICCE in Brazilian athletes.

\section{Method}

\section{Participants}

The population consisted of male and female athletes over 12 years of age. Based on the indications by DeVellis (2003), who determines 10 participants for each items of a psychometric tool and considering that the EICCE consisted of 31 items, the sample size was calculated. A minimum sample size of 310 athletes of each sex was determined for the psychometric validation. In view of the sample losses in other studies (Fortes, Kakeshita, et al., 2014; Fortes, Neves, Filgueiras, Almeida, \& Ferreira, 2013), we decided to add $20 \%$. Hence, in this study, a sample size of 372 athletes was adopted for each sex.

The following inclusion criteria were adopted: (a) to present the Free and Informed Consent Form signed by the responsible caregiver (if younger than 18 years) and sign the Assent Term; (b) systematically train one's respective sports modality with a minimum training regimen of six hours per week (e.g., minimum frequency of three days per week and duration of two hours/training or frequency of six days per week and duration of one hour/training); (c) minimal participation in one regional competition in 2014 and; (d) availability to answer the questionnaires and participate in the anthropometric assessments. In addition, the following exclusion criteria were adopted: (a) present physical or intellectual disability (indicated by the trainer) and; (b) having used psychoactive drugs in the past six months (indicated by the athlete).

In total, 854 male and 556 female athletes were included in the study. Nevertheless, 141 male and 72 female athletes were excluded because they did not answer the entire questionnaires and/or did not participate in the verification of the anthropometric measures, resulting in a final sample of 713 male athletes: Athletics $(n=19)$, Basketball $(n=68)$, Boxing $(n=12)$, Canoeing $(n=9)$, Cycling $(n=16)$, Soccer $(n=$ 83), Handball $(n=29)$, Horse riding $(n=5)$, Jiu-Jitsu $(n=$ 39), Judo $(n=38)$, Olympic weight lifting $(n=6)$, Swimming $(n=136)$, Water Polo $(n=24)$, Rowing $(n=23)$, Rugby $(n=$ $17)$, Diving $(n=6)$, Surfing $(n=69)$, Tae-kwon-do $(n=12)$, Tennis $(n=5)$, Triathlon $(n=15)$, Sailing $(n=9)$, Volleyball $(n=52)$ and Beach Volley $(n=21)$. What the female sex is concerned, 484 athletes were investigated, including: Athletics $(n=8)$, Basketball $(n=34)$, Boxing $(n=6)$, Cycling $(n=$ $11)$, Soccer $(n=36)$, Artistic Gymnastics $(n=28)$, Rhythmic 
gymnastics $(n=11)$, Handball $(n=33)$, Jiu-Jitsu $(n=26)$, Judo $(n=30)$, Synchronized swimming $(n=38)$, Swimming $(n=84)$, Figure Skating $(n=17)$, Water Polo $(n=15)$, Rowing $(n=6)$, Diving $(n=4)$, Surfing $(n=10)$, Tae-kwon-do $(n=7)$, Tennis $(n=8)$, Triathlon $(n=4)$, Sailing $(n=3)$, Volleyball $(n=57)$ and Beach Volley $(n=8)$. The participants in this research were affiliated with clubs from eight Brazilian states (Ceará, Minas Gerais, Paraíba, Pernambuco, Paraná, Rio de Janeiro, Rio Grande do Sul and São Paulo).

\section{Instruments}

The deductive method was used (DeVellis, 2003) to elaborate the EICCE. Hence, the initial creation of the items was based on the findings from three qualitative studies (de Bruin et al., 2011; Francisco et al., 2013; Plateau, McDermott, Arcelus, \& Meyer, 2014) and the appointments by authors of one systematic review (Varnes et al., 2013). The EICCE (elaborated by the researchers) is intended to assess the dissatisfaction and frequency of body checking in the athletes. It consists of a tool with 31 items on a five-point Likert scale ( $0=$ never, 1 = rarely, 2 = sometimes, 3 = almost always, 4 = always), which are intended to assess frequent body-checking feelings, thoughts and behaviors in the sports context. The higher the score, the greater the extent of the body dissatisfaction and/or body-checking frequency.

The assess the body dissatisfaction driven towards thinness (aversion of obesity), the Body Shape Questionnaire BSQ (P. J. Cooper et al., 1987) was applied. The BSQ was constructed by P.J. Cooper et al. (1987). This 34-question test contains questions intended to assess the subject's concern with his weight and body shape. The version used by subjects aged 18 years or younger was validated for Brazilian adolescents (Conti, Cordás, \& Latorre, 2009). Its internal consistency analysis revealed an $\alpha$ of 0.96 for both sexes and a significant correlation coefficient between the test-retest scores, ranging from .89 to .91 for girls and boys, respectively. The BSQ version used for athletes over 18 years of age was validated for the Brazilian young population (Di Pietro \& Silveira, 2009). The addition of its items results in the BSQ score. The higher the score, the greater the dissatisfaction driven towards thinness (aversion of obesity). It is highlighted that the items of the BSQ versions for adults and adolescents are identical. For the present study sample, Cronbach's $\alpha$ coefficients of .94 and .95 were identified for the male and female sex, respectively.

To assess the drive for muscularity, the Muscularity-oriented body image subscale of the DMS (McCreary et al., 2004). The DMS was elaborated by McCreary et al. (2004) and validated for the Brazilian population by Campana, Tavares, Swami and Silva (2013). It consists of a self-reported five-item subscale on a six-point scale $(1=$ never to $6=$ always). The higher the score, the greater the concern with being more muscular. The validation study of the DMS showed good psychometric properties for Brazilian men (Campana et al., 2013). In this study, a Cronbach's alpha coefficient of .81 was identified for both sexes.

The body-checking behaviors in the male sex were as- sessed by means of the MBCQ (Hildebrandt et al., 2010). The MBCQ was constructed by Hildebrandt et al. (2010) and validated for the Brazilian young male population, revealing good psychometric properties (Carvalho, Conti, Ribeiro, Amaral, \& Ferreira, 2014). For this sample, the internal consistency was calculated, as represented by the Cronbach's alpha coefficient $=.94$.

The body-checking behaviors in the female sex were assessed using the BCAQ (Shafran et al., 2004). The BCAQ was created by Shafran et al. (2004) and was validated for the Brazilian young female population with good psychometric properties (Kachani et al., 2011). For this sample, the internal consistency was calculated, as represented by Cronbach's alpha $=.93$.

To assess the risk behavior for eating disorders, the Eating Attitudes Test (EAT-26) was applied, created by Garner, Olmsted, Bohr and Garfinkel (1982). The questionnaire consists of 26 questions, distributed in three subscales: diet; bulimia and concern with foods and; oral self-control. The final score on the EAT-26 is obtained by adding up its items. There are six alternative answers, ranging from 0 to 3 points (always $=3$, often $=2$, frequently $=1$, rarely $=0$, hardly ever $=0$ and never $=0)$. The only question with an inverse score is 25 (always $=0$, often $=0$, frequently $=0$, rarely $=1$, hardly ever $=2$ and never $=3$ ). The version used was validated for the Brazilian population (Bighetti, C.B. Santos, J.E. Santos, \& Ribeiro, 2004), with an internal consistency coefficient of 0.82 . For this study, Cronbach's alpha was calculated, corresponding to .88 for the male sex and .89 for the female sex. As some findings demonstrate a relation between body image and risk behaviors for eating disorders in athletes (de Bruin et al., 2011; Fortes et al., 2013; Plateau et al., 2014), we decided to use the EAT-26 as a predictive validity criterion. Hence, the two-week interval was used to verify whether the EICCE could predict the EAT-26 scores, according to the method used in another research (Galli, Reel, Petrie, Greenleaf, \& Carter, 2011).

To calculate the body fat percentage $(\% \mathrm{G})$, a LANGE ${ }^{\circledR}$ (Cambridge Scientific Industries Inc.) adipometer was used with $1 \mathrm{~mm}$ precision to measure the cutaneous folds. The procedures to collect the cutaneous folds were carried out according to the standardizations of the International Society for the Advancement of Kineanthropometry (International Society for the Advancement of Kineanthropometry, 2013).

The $\% \mathrm{G}$ was estimated using the protocols by Slaughter et al. (1988) [the ethnic origin and maturation phase were considered in function of the chronological age (adolescent - 12 to 14 years; and post-adolescent - 15 to 17 years)], Jackson and Pollock (1978) and Jackson, Pollock and Ward (1980), created for adolescents and male and female adults, respectively.

Body fatness (male sex: $<6 \%=$ very low; $>7 \%$ and $<$ $12 \%=1 \mathrm{ow} ;>13 \%$ and $<18 \%=$ normal; $>19 \%$ and $<25 \%$ $=$ moderately high; $>26 \%$ and $<32 \%=$ high; $>32 \%=$ very high; female sex: $<11 \%=$ very low; $>12 \%$ and $<15 \%=$ low; $>16 \%$ and $<25 \%=$ normal; $>26 \%$ and $<30 \%=$ moderately high; $>31 \%$ and $<35 \%=$ high; $>35 \%=$ very high) was classified according to the cut-off points established by Lohman 
(1987). Next, the classifications "very low" and "low" were classified under "low body fatness", "normal" and "moderately high" under "normal body fatness" and "high" and "very high" under "high body fatness".

To measure the body mass, Tanita $^{\circledR}$ portable digital scales were used with $0.1 \mathrm{~kg}$ precision and maximum weight of $220 \mathrm{~kg}$. A Tonelli ${ }^{\circledR}$ portable stadiometer was used with 0.1 $\mathrm{cm}$ precision and maximum height of $2.20 \mathrm{~m}$ to measure the athletes' height. The body mass index (BMI) was obtained by calculating: $\mathrm{BMI}=$ body mass $(\mathrm{kg}) /$ height $\left(\mathrm{m}^{2}\right)$.

\section{Procedure}

Data collection. The trainers of different teams in several sports modalities were contacted to explain the study procedures and objectives. After the trainers had consented, a meeting was scheduled with each team to talk with the athletes and explain all ethical research procedures.

The study was divided in two phases. The first served to apply the questionnaires EICCE, BSQ, DMS, MBCQ (male sex) and BCAQ (female sex). It is highlighted that only one researcher was responsible for applying the instruments. This caution was taken to avoid different explanations and the influence of other researchers in the completion of the questionnaires.

During the collection, the athletes received the same verbal and written orientations about the appropriate procedures as given in the questionnaires. The researcher responsible for applying the tools clarified any doubts. No communication occurred among the subjects. The questionnaires were distributed when the athletes entered the room and completion happened on a voluntary base. No time limit was set for the completion.

In the second phase, undertaken soon after the completion of the questionnaires, the anthropometric measures were verified (body mass, height and skin folds). The clubs that participated in the research provided for appropriate rooms for the assessments. The measures were taken individually to avoided interference from team members.

These procedures took place in clubs and/or at competitions in 11 cities located in eight Brazilian states over a ten-month period, until reaching the desired sample size. It should be highlighted that each team was visited only once.

To assess the reliability of the EICCE, yet another phase was used at a two-week interval for the retest. Hence, 100 athletes of each sex were randomly chosen from different sports modalities (soccer, judo, swimming and volleyball) to answer the EICCE again. A two-week interval was also used to analyze the predictive validity of the EICCE. Thus, all athletes completed the EAT-26 two weeks after having completed the EICCE.
Data analysis. Exploratory factor analysis (principal components) was used with principal axis factoring and oblique Varimax rotation to extract the factors of the EICCE. The factor solution was used that answered a scale variance superior to $40 \%$. In addition, the factors were only considered if they consisted of three or more items with loadings superior to 0.3. Also, the EICCE items that presented factor loadings superior to 0.3 in more than one factor were excluded from the analyses, following recommendations by DeVellis (2003). Cronbach's alpha was used to analyze the internal consistency of the EICCE and its subscales. The Kolmogorov Smirnov test was applied to assess the data distribution. Due to the test result for the EICCE scores, parametric techniques were chosen. Hence, Pearson's correlation as used for the concurrent validity (relation between the EICCE subscales and the other instruments). To assess the reproducibility of the EICCE, Student's t-test was used to compared the EICCE test-retest scores (two-week interval). The intraclass correlation $\left(\mathrm{r}_{\text {intraclass }}\right)$ was conducted to related the EICCE item scores in the test-retest. For the discriminant validity, univariate covariance analysis (ANCOVA) was used, controlling for age, to compare the EICCE scores in function of the fat percentage classifications (low, normal and high). Bonferroni's post hoc test was used to identify which groups differed. In addition, Cohen's effect size was calculated, represented by " $d$ ", to indicate the importance of the findings from a practical viewpoint. Finally, the simple linear regression was conducted to analyze whether the EICCE could predict the EAT-26 scores, with a view to assessing the predictive validity of the EICCE. The data were treated in SPSS 21.0 with a 5\% significance level.

\section{Ethical Considerations}

Approval for the project was obtained from the Ethics Committee for Research involving Human Beings at the Faculty of Philosophy, Sciences and Letters at Ribeirão Preto (CAAE - 05166712.8.000.5407). The responsible caregivers (athletes younger than 18 years) signed a free and informed consent term in which the objectives and researcher procedures were explained. All athletes (younger and older than 18 years) signed the Assent Term, agreeing to participate in the research voluntarily. The participants' anonymity was guaranteed, as well as secrecy in the treatment of the data.

\section{Results}

The demographic characteristics of the athletes in this study are displayed in Table 1. 
Table 1

Demographic Characteristics of Athletes who Participated in the Study

\begin{tabular}{|c|c|c|c|c|}
\hline \multirow[t]{3}{*}{ Variable } & \multicolumn{4}{|c|}{ Sex } \\
\hline & \multicolumn{2}{|c|}{ Female $(N=484)$} & \multicolumn{2}{|c|}{ Male $(N=713)$} \\
\hline & $M(S D)$ & Min - Max & $M(S D)$ & Min - Max \\
\hline Age (years) & $17.11(1.55)$ & $12.00-36.00$ & $17.88(1.34)$ & $12.00-41.00$ \\
\hline Length of practice (years) & $8.76(2.33)$ & $3.00-24.00$ & $9.60(1.95)$ & $2.00-28.00$ \\
\hline Weekly training regimen (hours) & $12.71(2.89)$ & $6.00-36.00$ & $13.51(2.24)$ & $6.00-42.00$ \\
\hline Fat percentage & $21.60(4.48)$ & $9.23-32.45$ & $17.73(5.01)$ & $4.31-29.70$ \\
\hline \multirow[t]{2}{*}{ Body mass index $\left(\mathrm{kg} / \mathrm{m}^{2}\right)$} & $22.97(1.32)$ & $15.29-30.10$ & $23.56(1.22)$ & $16.39-30.85$ \\
\hline & $N$ & $\%$ & $N$ & $\%$ \\
\hline \multicolumn{5}{|l|}{ Age range } \\
\hline $12-18$ years & 262 & 54 & 359 & 50 \\
\hline $18-25$ years & 145 & 30 & 230 & 32 \\
\hline$>25$ years & 77 & 16 & 124 & 18 \\
\hline \multicolumn{5}{|l|}{ Competition level } \\
\hline Regional & 93 & 19 & 46 & 7 \\
\hline State & 160 & 33 & 250 & 35 \\
\hline National & 104 & 22 & 231 & 32 \\
\hline International & 127 & 26 & 187 & 26 \\
\hline \multicolumn{5}{|l|}{ Ethnic origin } \\
\hline White & 288 & 60 & 306 & 43 \\
\hline Black & 81 & 16 & 214 & 30 \\
\hline Yellow & 44 & 9 & 61 & 9 \\
\hline Mulatto & 71 & 15 & 132 & 18 \\
\hline
\end{tabular}

Note. $M=$ Mean; $S D=$ Standard deviation; Min = Minimum; Max = Maximum; $N=$ absolute sample size; $\%=$ relative sample size.

The factor analysis of the 31 items in the female version of the EICCE indicated a three-factor solution that explained $44.8 \%$ of its variance. This analysis revealed a coefficient of 0.89 for the Kaiser-Meyer-Olkin (KMO) and 3,845.63 ( $p=$ $.001)$ for Bartlett's sphericity test. The communalities of all items were superior to 0.28 . Nevertheless, items 20 ("I avoid showing my body to the public during the competitions"), 23 ("I check my body before and after the training sessions") and 28 ("I'm ashamed of using my competition uniform") demonstrated factor loadings inferior to 0.30 , and were therefore excluded from the subsequent analyses.

The factor analysis with the 29 items of the female version of the EICCE revealed a three-factor solution that explained $49.34 \%$ of the variance in the EICCE. The coefficients found were 0.87 for the KMO and 3,633.07 ( $p=.001)$ for Bartlett's sphericity test. The communalities of all items were superior to 0.14 . Nevertheless, items 1 ("I feel well when I notice that other athletes appreciate my body"), 9 ("I would like to modify my weight to improve my performance in competitions"), 27 ("Before the training sessions, I usually think that I should lose weight") and 29 ("I think I am fat when my competition results are not satisfactory") demonstrated factor loadings superior to 0.3 in more than one factor, culminating in the exclusion of these items from subsequent analyses.

The third factor analysis of the female version, conducted with 24 items, appointed a three-factor solution that explained $50.76 \%$ of the variance in the EICCE. Again, the KMO (0.86) and the Bartlett's sphericity test $(3,491.50)$ coefficients were significant $(p=.001)$. The communalities of all items were superior to 0.12 . Nevertheless, item 18 ("I envy other athletes' body") indicated a factor loading of more than 0.3 in more than one factor. Therefore, we decided to exclude it from the subsequent factor analysis.

Finally, a fourth factor analysis was conducted, involving 23 items, which demonstrated a three-factor solution that explained $47.78 \%$ of the variance in the female version of the EICCE. The coefficient for the KMO test was 0.83 and, for Bartlett's sphericity test, 3,281.13 ( $p=.001)$. The communalities of all items were superior to 0.22 . The factor loadings of all items were superior to 0.3 . In addition, it should be highlighted that the findings for all items demonstrated factor loading in a single factor, as indicated in Table 2. 
Table 2

Factor Analysis of the Female Version of the EICCE

\begin{tabular}{|c|c|c|c|c|}
\hline Items & Questions & Factor 1 & Factor 2 & Factor 3 \\
\hline 2 & Acredito que o meu peso está adequado para atingir bom desempenho no esporte que pratico & - & 0.64 & - \\
\hline 3 & Penso que sou magra o suficiente para as exigências do meu esporte & - & 0.56 & - \\
\hline 4 & Aprecio a minha aparência física após os treinamentos & - & 0.37 & - \\
\hline 5 & Durante os treinos, costumo checar o quanto há de gordura em meu corpo & - & - & 0.38 \\
\hline 6 & Gosto quando noto que reduzi o meu percentual de gordura corporal & 0.76 & - & - \\
\hline 7 & Fico satisfeita quando perco peso após os treinamentos & 0.86 & - & - \\
\hline 8 & Gostaria de ser mais magra para melhorar o meu rendimento nos treinos & 0.74 & - & - \\
\hline 10 & Comparo a minha gordura corporal com a das minhas adversárias & - & - & 0.65 \\
\hline 11 & Fico satisfeita com a minha magreza durante as competições & - & 0.73 & - \\
\hline 12 & Aprecio o meu peso corporal após atingir resultados satisfatórios em competições & - & 0.62 & - \\
\hline 13 & Utilizo roupas largas para evitar que as minhas colegas vejam o meu corpo durante os treinamentos & - & - & 0.71 \\
\hline 14 & Fico contente com a minha aparência física durante as competições & - & 0.71 & - \\
\hline 15 & Comparo a quantidade de gordura em meu corpo com a das minhas colegas de equipe & - & - & 0.70 \\
\hline 16 & Acredito que o meu percentual de gordura é valorizado em meu esporte & - & 0.65 & - \\
\hline 17 & Gosto quando reduzo o meu peso em véspera de competições & 0.72 & - & - \\
\hline 19 & Fico insatisfeita quando não atinjo o peso considerado adequado para as competições & 0.49 & - & - \\
\hline 21 & Gostaria de ser mais magra para melhorar o meu desempenho em competições & 0.68 & - & - \\
\hline 22 & Gosto do meu corpo quando estou treinando & - & 0.65 & - \\
\hline 24 & Após os eventos competitivos, fico satisfeita com a minha aparência física & - & 0.67 & - \\
\hline 25 & Gostaria de ganhar peso quando estou treinando & 0.66 & - & - \\
\hline 26 & Acho que outras atletas têm o corpo mais bonito que o meu & - & - & 0.57 \\
\hline 30 & Não gosto quando outras atletas olham para o meu corpo & - & - & 0.58 \\
\hline 31 & Fico realizada quando me sinto magra após os treinamentos & -0.71 & - & - \\
\hline \multicolumn{2}{|r|}{$\%$ of explained variance } & 27.45 & 25.49 & 13.98 \\
\hline \multicolumn{2}{|c|}{$\alpha$ Cronbach } & 0.77 & 0.72 & 0.74 \\
\hline \multicolumn{2}{|c|}{ Kaiser-Meyer-Olkin (KMO) } & 0.83 & $p<.001$ & - \\
\hline \multicolumn{2}{|c|}{ Batlett test } & $3,281.13$ & $p<.001$ & - \\
\hline
\end{tabular}

Note. Factor 1 = "Body dissatisfaction and performance in sports" [items 25 and 31 have an inverted score $(4=$ Never, $3=$ Rarely, $2=$ Sometimes, 1 = Almost Always, $0=$ Always)], Factor $2=$ "Satisfaction with weight and body appearance in sports" [all items present an inverted score $(4=$ Never, $3=$ Rarely, $2=$ Sometimes, $1=$ Almost Always, $0=$ Always $)$ ], Factor $3=$ "Body checking in the sports environment".

The factor analysis involving the 31 items in the male version of the EICCE indicated a nine-factor solution that explained $60 \%$ of its variance. This analysis revealed a KMO coefficient of 0.84 and Bartlett's sphericity test appointed a coefficient of 3,655.79 $(p=.001)$. The communalities of all items were superior to 0.32 . The factor loadings of all items were superior to 0.3 . Nevertheless, some of the factors consisted of less than three items. Therefore, we chose to undertake a new analysis, forcing the five-factor solution.

The five-factor solution explained $46 \%$ of the variance in the male version of the EICCE. The KMO coefficient corresponded to 0.84 and, for Bartlett's sphericity test, the coefficient was 3,632.04 ( $p=.001)$. The communalities of all items were superior to 0.29 . Nevertheless, items 1 ("I feel well when I notice that other athletes appreciate my body"), 4 ("I appreciate my physical appearance after the training sessions"), 19 ("I feel dissatisfied when I do not reach the appropriate weight for the competitions"), 26 ("I think other athletes have a more beautiful body than mine") and 27 ("I would like to gain weight when I am training") demonstrated a factor loading superior to 0.3 in more than one factor, culminating in the exclusion of these items in the subsequent analyses.

The third factor analysis, involving 26 items, appointed a five-factor solution that explained $49 \%$ of the variance in the male version of the EICCE. Again, the coefficients for the KMO (0.82) and Bartlett's sphericity test $(3,370.41)$ were significant $(p=.001)$. The communalities of all items were superior to 0.23 . Nevertheless, items 23 ("I check my weight before or after the training sessions") and 29 ("I find myself hardly muscular when my competition results are not satisfactory") indicated factor loading superior to 0.3 in more than one factor. Therefore, they were excluded from the subsequent factor analysis.

Finally, a fourth factor analysis was conducted with 24 items, which demonstrated a five-factor solution that explained $51 \%$ of the variance in the male version of the EICCE. The coefficient for the KMO test was 0.80 and, for Bartlett's sphericity test, $3,171.02(p=.001)$. The communalities of all 
items were superior to 0.24 . The factor loadings of all items were superior to 0.3 . In addition, it should be highlighted that the findings for all items demonstrated factor loading in a single factor, as indicated in Table 3.

The internal consistency results appointed a Cronbach's alpha coefficient of 0.87 for the female version of the EICCE.
The same test indicated coefficients of $0.77,0.72$ and 0.74 for Factors 1, 2 and 3, respectively (Table 2). For the male version of the EICCE, the findings indicated an internal consistency coefficient of 0.83 . The coefficients for Factors 1, 2, 3, 4 and 5 equaled $0.81,0.70,0.70,0.73$ and 0.65 , respectively (Table 3).

Table 3

Factor Analysis of Male Version of the EICCE

\begin{tabular}{|c|c|c|c|c|c|c|}
\hline Items & Questions & Factor 1 & Factor 2 & Factor 3 & Factor 4 & Factor 5 \\
\hline 2 & $\begin{array}{l}\text { Acredito que o meu peso está adequado para atingir um bom desempe- } \\
\text { nho no esporte que pratico }\end{array}$ & 0.64 & - & - & - & - \\
\hline 3 & $\begin{array}{l}\text { Acho que os meus músculos são suficientemente volumosos para as } \\
\text { exigências do meu esporte }\end{array}$ & 0.55 & - & - & - & - \\
\hline 5 & Durante os treinos, costumo checar o tamanho dos meus músculos & - & 0.65 & - & - & - \\
\hline 6 & Gosto quando noto que os meus músculos aumentaram & - & 0.50 & - & - & - \\
\hline 7 & Fico realizado quando diminuo o peso após os treinamentos & - & - & - & 0.79 & - \\
\hline 8 & Gostaria de ser mais musculoso para melhorar o meu rendimento nos treinos & - & - & 0.79 & - & - \\
\hline 9 & $\begin{array}{l}\text { Gostaria de modificar o meu peso para melhorar o meu desempenho } \\
\text { em competições }\end{array}$ & - & - & 0.53 & - & - \\
\hline 10 & Comparo o meu volume muscular com o dos meus adversários & - & 0.60 & - & - & - \\
\hline 11 & Fico satisfeito com a minha definição muscular durante as competições & 0.64 & - & - & - & - \\
\hline 12 & $\begin{array}{l}\text { Aprecio o meu peso corporal após atingir resultados satisfatórios em } \\
\text { competições }\end{array}$ & 0.53 & - & - & - & - \\
\hline 13 & $\begin{array}{l}\text { Utilizo roupas largas para evitar que os meus colegas vejam o meu } \\
\text { corpo durante os treinamentos }\end{array}$ & - & - & - & - & 0.59 \\
\hline 14 & Fico contente com a minha aparência física durante as competições & 0.71 & - & - & - & - \\
\hline 15 & Comparo o tamanho dos meus músculos com o dos meus colegas de equipe & - & 0.80 & - & - & - \\
\hline 16 & Acredito que a minha aparência muscular é valorizada em meu esporte & 0.52 & - & - & - & - \\
\hline 17 & Gosto quando reduzo o meu peso em véspera de competições & - & - & - & 0.80 & - \\
\hline 18 & Sinto inveja do corpo de outros atletas & - & 0.62 & - & - & - \\
\hline 20 & Evito expor o meu corpo ao público durante as competições & - & - & - & - & 0.63 \\
\hline 21 & Antes dos treinamentos, costumo pensar que deveria reduzir o meu peso & - & - & - & 0.76 & - \\
\hline 22 & Gosto do meu corpo quando estou treinando & 0.70 & - & - & - & - \\
\hline 24 & $\begin{array}{l}\text { Gostaria que a minha massa muscular fosse mais avantajada para me- } \\
\text { lhorar o meu desempenho em competições }\end{array}$ & - & - & 0.81 & - & - \\
\hline 25 & Após os eventos competitivos, fico satisfeito com a minha aparência física & 0.66 & - & - & - & - \\
\hline 28 & Tenho vergonha de utilizar meu uniforme de competição & - & - & - & - & 0.46 \\
\hline 30 & Não gosto quando outros atletas olham para o meu corpo & - & - & - & - & 0.80 \\
\hline 31 & Fico satisfeito com o tamanho dos meus músculos após os treinamentos & 0.69 & - & - & - & - \\
\hline \multicolumn{2}{|c|}{$\%$ of explained variance } & 15.98 & 9.72 & 9.19 & 8.81 & 7.53 \\
\hline \multicolumn{2}{|c|}{$\alpha$ Cronbach } & 0.81 & 0.70 & 0.70 & 0.73 & 0.65 \\
\hline \multicolumn{2}{|c|}{ Kaiser-Meyer-Olkin (KMO) } & 0.80 & $\mathrm{p}<.001$ & - & - & - \\
\hline \multicolumn{2}{|c|}{ Batlett test } & $3,171.02$ & $\mathrm{p}<.001$ & - & - & - \\
\hline
\end{tabular}

Note. Title of subscales: Factor $1=$ Body satisfaction in the sports environment [all items in this Factor have an inverted score $(4=$ Never, $3=$ Rarely, $2=$ Sometimes, $1=$ Almost Always, $0=$ Always $)$, Factor $2=$ Muscle checking in sports, Factor $3=$ Body dissatisfaction and sports performance, Factor $4=$ Dissatisfaction with body weight in sports, Factor $5=$ Body avoidance in sports. 
In Table 4, the concurrent validity results of the EIC$\mathrm{CE}$ are presented. Pearson's correlation demonstrated a statistically significant relation between the female version of the EICCE, the BSQ, the DMS and the BCAQ $(p \leq 0.001)$. Similarly, the results demonstrated a statistically significant relation between the male version of the EICCE, the BSQ, the DMS e o MBCQ $(p \leq .001)$.
With regard to the reproducibility, no difference of means was identified between the scores for the female $\left(F_{(2,482)}\right.$ $=2.86, t=1.41, p=.38, d=0.1)$ and male versions $\left(F_{(2,711)}=\right.$ $3.55, t=1.60, p=.42, d=0.1)$ of the EICCE at a two-week interval. In addition, the intraclass correlation coefficient demonstrated statistical significance for the female $(r=0.89, p$ $=0.001)$ and male versions $(r=0.91, p=0.001)$, indicating good reproducibility of the EICCE.

Table 4

Statistical Data of Concurrent Validity (Female and Male Version of EICCE vs. BSQ, DMS, BCAQ and MBCQ) and Reproducibility (T1 vs. T2)

\begin{tabular}{|c|c|c|c|c|}
\hline $\begin{array}{c}\text { Analysis } \\
\text { Female Sex }\end{array}$ & Variable & Parameter & \multicolumn{2}{|c|}{$p$} \\
\hline \multirow[t]{12}{*}{ Correlation } & EICCE vs. BSQ & Pearson & $r=.73$ & .001 \\
\hline & Factor 1 EICCE vs. BSQ & & $r=.59$ & .001 \\
\hline & Factor 2 EICCE vs. BSQ & & $r=.41$ & .001 \\
\hline & Factor 3 EICCE vs. BSQ & & $r=.56$ & .001 \\
\hline & EICCE vs. subscale DMS & & $r=.26$ & .001 \\
\hline & Factor 1 EICCE vs. subscale DMS & & $r=.21$ & .001 \\
\hline & Factor 2 EICCE vs. subscale DMS & & $r=.09$ & .12 \\
\hline & Factor 3 EICCE vs. subscale DMS & & $r=.23$ & .001 \\
\hline & EICCE vs. BCAQ & & $r=.30$ & .001 \\
\hline & Factor 1 EICCE vs. BCAQ & & $r=.19$ & .001 \\
\hline & Factor 2 EICCE vs. BCAQ & & $r=.23$ & .001 \\
\hline & Factor 3 EICCE vs. BCAQ & & $r=.29$ & .001 \\
\hline Reproducibility (T1 vs. T2) & EICCE score & Student's T & $t=1.41$ & .42 \\
\hline Male Sex & EICCE items & $\mathrm{r}_{\text {icc }}$ & $r=.89$ & .001 \\
\hline \multirow[t]{18}{*}{ Correlation } & EICCE vs. BSQ & Pearson & $r=.47$ & .001 \\
\hline & Factor 1 EICCE vs. BSQ & & $r=.08$ & .16 \\
\hline & Factor 2 EICCE vs. BSQ & & $r=.33$ & .001 \\
\hline & Factor 3 EICCE vs. BSQ & & $r=.30$ & .001 \\
\hline & Factor 4 EICCE vs. BSQ & & $r=.37$ & .001 \\
\hline & Factor 5 EICCE vs. BSQ & & $r=.32$ & .001 \\
\hline & EICCE vs. subscale DMS & & $r=.47$ & .001 \\
\hline & Factor 1 EICCE vs. subscale DMS & & $r=.14$ & .001 \\
\hline & Factor 2 EICCE vs. subscale DMS & & $r=.35$ & .12 \\
\hline & Factor 3 EICCE vs. subscale DMS & & $r=.52$ & .001 \\
\hline & Factor 4 EICCE vs. subscale DMS & & $r=.05$ & .13 \\
\hline & Factor 5 EICCE vs. subscale DMS & & $r=.17$ & .001 \\
\hline & EICCE vs. MBCQ & & $r=.42$ & .001 \\
\hline & Factor 1 EICCE vs. MBCQ & & $r=-.10$ & .12 \\
\hline & Factor 2 EICCE vs. MBCQ & & $r=.57$ & .001 \\
\hline & Fctor 3 EICCE vs. MBCQ & & $r=.31$ & .001 \\
\hline & Factor 4 EICCE vs. MBCQ & & $r=.15$ & .001 \\
\hline & Factor 5 EICCE vs. MBCQ & & $r=.27$ & .001 \\
\hline \multirow[t]{2}{*}{ Reproducibility (T1 vs. T2) } & EICCE score & Student's T & $t=1.60$ & .47 \\
\hline & EICCE items & $r_{i c c}$ & $r=.91$ & .001 \\
\hline
\end{tabular}

Note. EICCE $=$ Scale of Dissatisfaction and Body Checking in Sports, BSQ = Body Shape Questionnaire, DMS $=$ Drive for Muscularity Scale, BCAQ = Body Checking and Avoidance Questionnaire, MBCQ = Male Body Checking Questionnaire. 
What the discriminant validity is concerned, ANCOVA revealed a statistically significant difference between the scores for the female $\left(F_{(3,481)}=42.09, p=0,01, d=0.5\right)$ and male versions $\left(F_{(3,710)}=36.01, p=0.01, d=0.5\right)$ of the EICCE in function of the body fatness classifications. In the female sex, the "high body fatness" group demonstrated a higher EICCE score when compared to the "normal body fatness" $\left(F_{(2,344)}=\right.$ $33.45, p=.01, d=0.5)$ e "low body fatness" $\operatorname{groups}\left(F_{(2,290)}=\right.$ $64.73, p=.001, d=0.6)$. Similarly, the group "normal body fatness" indicated a higher EICCE score when compared to the "low body fatness" group $\left(F_{(2,360)}=39.51, p=.01, d=\right.$ $0.5)$. In the male sex, the "high body fatness" group demonstrated a higher EICCE score when compared to the "normal body fatness" $\left(F_{(2,526)}=29.92, p=.01, d=0.5\right)$ and "low body fatness" groups $\left(F_{(2,293)}=48.53, p=.001, d=0.6\right)$. In the same sense, the group "normal body fatness" indicated a higher EICCE score when compared to the "low body fatness" group $\left(F_{(2,539)}=24.60, p=.01, d=0.5\right)$.

What the predictive validity is concerned, the findings demonstrated a positive and statistically significant relation between the female version of the EICCE and the EAT-26 scores $\left(F_{(1,483)}=65.64, \mathrm{R}^{2}=0.19\right.$, Beta $=0.44, t=8.10, p=$ $.001)$. In the same sense, the results indicated a positive and statistically significant relation between the male version of the EICCE and the EAT-26 scores $\left(F_{(1,712)}=48.50, \mathrm{R}^{2}=0.10\right.$, Beta $=0.23, t=6.06, p=.001)$, using a two-week interval to complete the questionnaires.

\section{Discussion}

The premise underlying the research was the analysis of the psychometric validity of the EICCE in Brazilian female and male athletes. The findings demonstrated a factorial structure that explained more than $40 \%$ of the scale variance and internal consistency, with coefficients superior to 0.70 and 0.65 for all factors in the female and male versions, respectively. In addition, the versions of the EICCE indicated concurrent validity and appropriate reproducibility, assessed at a two-week interval. Finally, the results revealed the discriminant and predictive validity of the EICCE based on the body fatness rankings and the relation with the EAT-26 scores, respectively.

The female version of the EICCE indicated a three-factor sector that explained $47.78 \%$ of its variance, as recommended by DeVellis (2003). Seven items had to be excluded from the scale because they did not present a minimal factor loading of 0.30 or because they demonstrated a factor loading of 0.30 or more in more than one factor. The male version of the EICCE demonstrated a five-factor structure that explained $51 \%$ of its variance. Seven items had to be excluded from the scale because they demonstrated a factor loading of 0.30 or more in more than one factor. It is highlighted that, in other studies reporting on the construction of a psychometric scale for athletes, items were also excluded to reach the final version of the scale (Martinsen, Holme, Pensgaard, Torstveit, \& Sundgot-Borgen, 2014; Scoffier, Paquet, Corrion, \& d'Arripe-Longueville, 2010), which supports the present findings.

What the internal consistency of the EICCE is concer- ned, coefficients superior to 0.70 were found for the total scale and all of its factors in the female version, in line with recommendations in the scientific literature (DeVellis, 2003). The male version of the EICCE also demonstrated the same or higher internal consistency for all factors, except for Factor 5, with a coefficient of 0.65 . Nevertheless, the authors highlight that the number of items influences the internal consistency of a subscale (Galli et al., 2011; McNamara \& McCabe, 2013). Hence, a subscale with few items can present an internal consistency coefficient inferior to 0.70 , which justifies the result for Factor 5, which only consisted of four items.

The findings revealed a statistically significant association (coefficients between 0.19 and 0.73 ) between the female version of the EICCE and the other measures (BSQ, DMS subscale and BCAQ). Similarly, the results demonstrated a statistically significant relation (coefficients between 0.14 and 0.57 ) between the male version of the EICCE and the other measures (BSQ, DMS subscale and MBCQ), supporting the results of the concurrent validity process in other validation studies of psychometric scales for athletes (Martinent, Decret, Isoard-Gautheur, Filaire, \& Ferrand, 2014; Mayville, Williamson, White, Netemeyer, \& Drab, 2002; McNamara \& McCabe, 2013). These findings indicate that, the higher the EICCE score, the higher the scores on other psychometric tools that assess body image constructs.

What the reproducibility is concerned, the test-retest results appointed no differences for the EICCE scores. Also, the intraclass correlation coefficient was statistically significant ( $\mathrm{r}$ $=0.89$ for the female sex and $r=0.91$ for the male). These findings indicated good stability of the EICCE over a two-week period, supporting psychometric experts' recommendations (Clark \& Watson, 1995; DeVellis, 2003).

In the discriminant validity analysis, the results demonstrated differences in the EICCE scores in relation to the body fatness classifications. Hence, the higher the body fatness, the higher the EICCE scores. In that sense, this finding appoints good discriminant validity of both instrument version, as findings from another scientific study revealed that athletes with higher body fatness were more concerned with their bodies (Fortes et al., 2014). That justifies the use of body fatness as a discriminant validity criterion of the EICCE.

With regard to the predictive validity, the simple linear regression demonstrated that both versions of the EICCE were able to predict the EAT-26 scores at a two-week interval. In that sense, $19 \%$ and $10 \%$ of the variance in the EAT-26 was explained based on the female and male versions of the EICCE, respectively. This predictive validity assessment method was adopted in the study by Galli et al. (2011). The authors revealed that the "Weight Pressures in Sport for Male Athletes" was able to predict the magnitude of bulimic symptoms in American male athletes, which somewhat supports the predictive validity results in this research.

Although the research reveals unedited findings, its limitations should be mentioned. Questionnaires were used as the main measures. Researchers affirm that individuals may not answer reliably to subjective tools (Fortes et al., 2015). Hence, the results may not reflect the reality of the context assessed, as the end result derives from subjective answers. Nevertheless, 
the relevance of these measures is emphasized, provided that they psychometric qualities are guaranteed (DeVellis, 2003). Despite this limitation, we believe that both versions (male and female) of the EICCE complied with the psychometric requisites needed, which justifies their use with athletes.

Based on the results, it could be concluded that the EIC$\mathrm{CE}$ demonstrated a three-factor structure for the female sex and a five-factor structure for the male sex, as well as satisfactory concurrent, discriminant and predictive validity and reproducibility. Therefore, it is assumed that the EICCE is a good measure to analyze dissatisfaction and body checking in athletes. This new scale can be used in practical (trainers), research and clinical contexts to analyze some body image constructs in the athletic population.

In addition, research is needed to assess the external validity of the EICCE. Finally, the adaptation and validation of the female and male versions of the EICCE to other languages and cultures is recommended, with a view to comparing the dissatisfaction and body checking among athletes from different countries.

\section{References}

Bighetti, F., Santos, C. B., Santos, J. E., \& Ribeiro, R. P. P. (2004). Tradução e validação do Eating Attitudes Test em adolescentes do sexo feminino de Ribeirão Preto, São Paulo [Translation and validation of the Eating Attitudes Test in female adolescents in Ribeirão] Preto, SP, Brazil]. Jornal Brasileiro de Psiquatria, 53(6), 339-346.

Campana, A. N. N. B., Tavares, M. C. G. C. F., Swami, V., \& Silva, D. (2013). An examination of the psychometric properties of Brazilian Portuguese translations of the Drive for Muscularity Scale, the Swansea Muscularity Attitudes Questionnaire, and the Masculine Body Ideal Distress Scale. Psychology of Men \& Masculinity, 14(4), 376-388. doi: $10.1037 / \mathrm{a} 0030087$

Carvalho, P. H. B., Conti, M. A., Ribeiro, M. S., Amaral, A. C. S., \& Ferreira, M. E. C. (2014). Avaliação psicométrica do Male Body Checking Questionnaire (MBCQ). Psicologia: Reflexão e Crítica, 27(4), 700-709. doi:10.1590/16787153.201427410

Clark L. A., \& Watson, D. (1995). Constructing validity: Basic issues in objective scale development. Psychological Assessment, 3, 309-319.

Conti, M. A., Cordás, T. A., \& Latorre, M. R. D. O. (2009). A study of the validity and reliability of the Brazilian version of the Body Shape Questionnaire (BSQ) among adolescents. Revista Brasileira de Saúde Materno Infantil, 9(3), 331-338. doi:10.1590/S1519-38292009000300012

Cooper, P. J., Taylor, M. J., Cooper, Z., \& Fairburn, C. G. (1987). The development and validation of Body Shape Questionnaire. International Journal of Eating Disorders, 6(4), 485-494. doi:10.1002/1098-108X(198707)6:4<485::AID-EAT2260060405>3.0.CO;2-O de Bruin, A. P., Oudejans, R. R. D., Bakker, F. C., \& Woertman, L. (2011). Contextual body image and athletes disordered eating: The contribution of athletic body image to disordered eating in high performance women athletes. European Eating Disorders Research, 19(3), 201-215. doi:10.1002/erv.1112

DeVellis, R. F. (2003). Scale development: Theory and applications (2nd ed.). Thousand Oaks, CA: Sage.

Di Pietro, M., \& Silveira, D. X. (2009). Internal validity, dimensionality and performance of the Body Shape Questionnaire in a group of Brazilian college students. Revista Brasileira de Psiquiatria, 31(1), 21-24. doi:10.1590/ S1516-44462008005000017

Fortes, L. S., Almeida, S. S., \& Ferreira, M. E. C. (2014). Influence of psychological, anthropometric and sociodemographic factors on the symptoms of eating disorders in young athletes. Paidéia (Ribeirão Preto), 24(57), 21-27. doi:10.1590/1982-43272457201404

Fortes, L. S., Ferreira, M. E. C., Oliveira, S. M. F., Cyrino, E. S., \& Almeida, S. S. (2015). A socio-sports model of disordered eating among Brazilian male athletes. Appetite, 92, 29-35. doi:10.1016/j.appet.2015.05.005

Fortes, L. S., Kakeshita, I. S., Almeida, S. S., Gomes, A. R., \& Ferreira, M. E. C. (2014). Eating behaviours in youths: A comparison between female and male athletes and non-athletes. Scandinavian Journal of Medicine \& Science in Sports, 24(1), e62-e68. doi:10.1111/sms.12098

Fortes, L. S., Neves, C. M., Filgueiras, J. F., Almeida, S. S., \& Ferreira, M. E. C. (2013). Body dissatisfaction, psychological commitment to exercise and eating behavior in young athletes from aesthetic sports. Revista Brasileira de Cineantropometria \& Desempenho Humano, 15(6), 695704. doi:10.5007/1980-0037.2013v15n6p695

Francisco, R., Narciso, I., \& Alarcão, M. (2013). Individual and relational risk factors for the development of eating disorders in adolescent aesthetic athletes and general adolescents. Eating and Weight Disorders, 18(4), 403-411. doi:10.1007/s40519-013-0055-6

Galli, N., Reel, J. J., Petrie, T., Greenleaf, C., \& Carter, J. (2011). Preliminary development of the weight pressures in sport scale for male athletes. Journal of Sport Behavior, 34(1), 47-68.

Garner, D. M., Olmsted, M. P., Bohr, Y., \& Garfinkel, P. E. (1982). The Eating Attitudes Test: Psychometric features and clinical correlates. Psychological Medicine, 12(4), 871-878. doi:10.1017/S0033291700049163

Garner, D. M., Olmstead, M. P., \& Polivy, J. (1983). Development and validation of a multidimensional eating disorder inventory for anorexia nervosa and bulimia. International Journal of Eating Disorders, 2(2), 15-34. doi:10.1002/ 1098-108X(198321)2:2<15::AID-EAT2260020203>3.0. $\mathrm{CO} ; 2-6$ 
Hildebrandt, T., Walker, D. C., Alfano, L., Delinsky, S., \& Bannon, K. (2010). Development and validation of a Male Specific Body Checking Questionnaire. International Journal of Eating Disorders, 43(1), 77-87. doi:10.1002/ eat.20669

International Society for the Advancement of Kineanthropometry. Australia. National Library of Australia. [Internet homepage] (2013) <http://www.isakonline.com>. [Last accessed 13.07.15.].

Jackson, A. S., \& Pollock, M. L. (1978). Generalized equations for predicting body density of men. British Journal of Nutrition, 40(3), 497-504.

Jackson, A. S., Pollock, M. L., \& Ward, A. (1980). Generalized equations for predicting body density of women. Medicine \& Science in Sports \& Exercise, 12(3), 175-82.

Kachani, A. T., Hochgraf, P. B., Brasiliano, S., Barbosa, A. L. R., Cordás, T. A., \& Conti, M. A. (2011). Psychometric evaluation of the "Body Checking and Avoidance Questionnaire - BCAQ" adapted to Brazilian Portuguese. Eating and Weight Disorders, 16(4), e293-299.

Laus, M. F., Kakeshita, I. S., Costa, T. M. B., Ferreira, M. E. C., Fortes, L. S., \& Almeida, S. S. (2014). Body image in Brazil: Recent advances in the state of knowledge and methodological issues. Revista de Saúde Pública, 48(2), 331-346. doi:10.1590/S0034-8910.2014048004950

Lohman, T. G. (1987). The use of skinfolds to estimate body fatness on children and youth. Journal of Physical Education, Recreational \& Dance, 58(9), 98-103. doi:10.1080/0 7303084.1987 .10604383

Martinsen, M., Holme, I., Pensgaard, A. M., Torstveit, M. K., \& Sundgot-Borgen, J. (2014). The development of the Brief Eating Disorder in Athletes Questionnaire. Medicine \& Science in Sport \& Exercise, 46(8), 1666-1675. doi:10.1249/MSS.0000000000000276

Martinent, G., Decret, J. C., Isoard-Gautheur, S., Filaire, E., \& Ferrand, C. (2014). Evaluations of the psychometric proprieties of the Recovery-Stress Questionnaire for athletes among a sample of young French table tennis players. Psychological Reports, 114(2), 326-340. doi:10.2466/03.14. PR0.114k18w2

Mayville, S. B., Williamson, D. A., White, M. A., Netemeyer, R. G., \& Drab, D. L. (2002). Development of muscle appearance satisfaction scale: A self-report measure for the assessment of muscle dysmorphia symptoms. Assessment, 9(4), 351-360. doi:10.1177/1073191102238156

McCreary, D. R., Sasse, D. K., Saucier, D. M., \& Dorsch, K. D. (2004). Measuring the drive for muscularity: Factorial validity of the Drive for Muscularity Scale in men and women. Psychology of Men \& Masculinity, 5(1), 49-58. doi:10.1037/1524-9220.5.1.49
McNamara, J., \& McCabe, M. P. (2013). Development and validation of the Exercise Dependence and Elite Athletes Scale. Performance Enhancement \& Health, 2(1), 30-36. doi:10.1016/j.peh.2012.11.001

Ochner, C. N., Gray, J. A., \& Brickner, K. (2009). The development and initial validation of a new measure of male body dissatisfaction. Eating Behaviors, 10(4), 197-201. doi:10.1016/j.eatbeh.2009.06.002

Petrie, T., Galli, N., Greenleaf, C., Reel, J., \& Carter, J. (2014). Psychosocial correlates of bulimic-symptomatology among male athletes. Psychology of Sport and Exercise, 15(6), 680-687. doi:10.1016/j.psychsport.2013.09.002

Plateau, C. R., McDermott, H. J., Arcelus, J., \& Meyer, C. (2014). Identifying and preventing disordered eating among athletes: Perceptions of track and field coaches. Psychology of Sport and Exercise, 15(6), 721-728. doi:10.1016/j.psychsport.2013.11.004

Reas, D. L., Whisenhunt, B. L., Netemeyer, R., \& Williamson, D. A. (2002). Development of the body checking questionnaire: A self-report measure of body checking behaviors. International Journal of Eating Disorders, 31(3), 324-333. doi:10.1002/eat.10012

Scoffier, S., Paquet, Y., Corrion, K., \& d'Arripe-Longueville, F. (2010). Development and validation of the French Self-regulatory Eating Attitude in Sports Scale. Scandinavian Journal of Medicine \& Science in Sports, 20(5), 696-705. doi:10.1111/j.1600-0838.2009.00984.x

Shafran, R., Fairburn, C. G., Robinson, P., \& Lask, B. (2004). Body checking and its avoidance in eating disorders. International Journal of Eating Disorders, 35(1), 93-101.

Slaughter, M. H., Lohman, T. G., Boileau, R. A., Horswill, C. A., Stillman, R. J., Van Loan, M. D., \& Bemben, D. A. (1988). Skinfold equations for estimation of body fatness in children and youth. Human Biology, 60(5), 709-723.

Varnes, J. R., Stellefson, M. L., Janelle, C. M., Dorman, S. M., Dodd, V., \& Miller M. D. (2013). A systematic review of studies comparing body image concerns among female college athletes and non-athletes, 1997-2012. Body Image, 10(4), 421-432. doi:10.1016/j.bodyim.2013.06.001

Walker, D. C., Anderson, D. A., \& Hildebrandt, T. (2009). Body checking behaviors in men. Body Image, 6(3), 164170. doi:10.1016/j.bodyim.2009.05.001

Walker, D. C., Murray, A. D., Lavender, J. M., \& Anderson, D. A. (2012). The direct effects of manipulating body checking in men. Body Image, 9(4), 462-468. doi:10.1016/j. bodyim.2012.06.001 
Leonardo de Sousa Fortes is a Professor at the Universidade Federal de Pernambuco.

Sebastião Sousa Almeida is a Full Professor at the Universidade de São Paulo.

Edilson Serpeloni Cyrino is a Full Professor at the Universidade Estadual de Londrina.

Maria Elisa Caputo Ferreira is an Adjunct Professor at the Universidade Federal de Juiz de Fora.

Received: May 14, 2015

1st Revision: Mar. 08, 2016

Approved: Apr. 01, 2016

How to cite this article:

Fortes, L. S., Almeida, S. S., Cyrino, E. S., \& Ferreira, M. E. C. (2017). Dissatisfaction and body checking in sports scale: A new measure for athletes. Paidéia (Ribeirão Preto), 27(67), 110-121. doi: 10.1590/1982-43272767201713 